IJTC

Ilomata International Journal of Tax \& Accounting

P-ISSN: 2714-9838; E-ISSN: 2714-9846

Vol. 1 No. 1 October 2019 page:1-11

https://www.ilomata.org/index.php/ijtc

\title{
Internal Control Analysis towards the Accounts Receivable Accounting System at STIAMI Institute
}

\author{
Iin Andrayanti \\ Institute of Social Science and Management STIAMI \\ Correspondence: inez_aulia@ymail.com
}

Submitted: 6 August 2019.

16 Sept 2019. $\quad$ Published: 30 October 2019.

Revised: 26 August,

\begin{abstract}
This research aims to reveal how internal control of the accounts receivable system, obstacles faced on the internal control applied, and the endeavors made to reduce it at STIAMI Institute. This research use descriptive-analytical methods to determine the implementation of internal control and account receivable system. Based on the result of the research, internal control towards the account receivable accounting system implemented on STIAMI is quite efficient, indicated by the independence of the audit committee or the internal supervisory unit (ISU) in which are right under the head of STIAMI auspices. In addition, STIAMI's management has applied basic concepts and principles of internal control. In STIAMI internal control activities, it is better to enforce the functions and centralization of the online system so that the operations and financial statement presentation can run effectively and efficiently.
\end{abstract}

Keywords: Internal control and accounts receivable system.

\section{INTRODUCTION}

Accounting has endured development throughout the everchanging era continuously. The increasingly complex business world has caused accounting concepts and techniques developed in which it can present information about financial positions, performance, and flow of funds of an economic unit to decision-makers.

The increasing competitiveness in business competition is an indicator of the exploding and rapid growth of the business world's impact. Fronting this circumstance, companies and their leaders are required to be able to create or upgrade the companies' value as well as managing the existing production factors in order to achieve the companies' goals. Companies are also required to be able to determine a good performance in such manner that the company would be able to warrant their sustainability. 
Analysis of the Accounts Receivable Internal Control System at STIAMI Institute Andrayanti

One of the competitive advantages which can be proposed by trading companies, as well as companies who offer service provision, is the flexibility of credit payment. Credit payment systems incur account receivable for trading companies or service companies and incur debts for customers or service users. Receivables that occur from sales or service-provision are the main activities of companies identified as trade receivables that are classified as current assets in the balance sheet. The number of receivables depends on the company management policies, such as credit and billing policies.

Remarking from liquidity aspect, receivable is a liquid tool after cash and banks. Consequently, to avoid contrary risks that can ensue due to the receivables, companies must have an adequate accounting system as the company's internal control tools to examine business activities. Accounts Receivable Accounting system aims to record the company's receivables mutations and receivables mutations caused by credit sales transactions and cash receipts from debtors (Ge \& McVay, 2005). Therefore, adequate internal control is needed to coordinate and supervise the company's activity, especially on receivables. This action meant to avoid any occurences that may cause harm to the company, for instance, misappropriation, fraud, dissipation, and theft from both inside and outside parties (Bentley-Goode, Newton, \& Thompson, 2017).

The internal control system has elements that need to be structured, scilicet authority system and responsibilities segregration, especially on operation and storage functions with accounting functions, as well as a restriction on giving full responsibility to perform all stages of a transaction to provide ample protection towards wealth, debt, revenue, and costs.

Internal control structure represented three things, videlicet control environment, accounting system, and ample control procedure in an organization would be able to help managements in securing both physical non-physical assets from abuse and fraud (Sofyan, 2016). In each organization, each transaction only consists of authorization from officials who have the authority to approve of the deal. Hence, organizations must establish a system that regulates the authority's arragement for sanction each transaction done. From the built system, the implementation would not run successfully if there is an unhealthy practice from the authorities simultaneously with incompetent and dishonest employees (Hoitash, Hoitash, \& Bedard, 2009).

In a reliable accounting system, there are supervision ways that could run by itself through a particular system plus procedure, the outcome of a part would be controlled by other parts through several various reports which reach the management. A good accounting system has to be able to summarize internal control principles and techniques, in 
Analysis of the Accounts Receivable Internal Control System at STIAMI Institute Andrayanti

which one of the attributes is to provide trustworthy information. Moreover, in managing financial management, notably accounts receivable, it needs to be planned and analyzed carefully, so that the policies of accounts receivable management can run effectively and efficiently, especially in the implementation of internal control over the existing accounts receivable accounting system (Beasley, Carcello, Hermanson, \& Lapides, 2000).

STIAMI Institue is a private-owned business engaged in education services, notably for undergraduate programs, which provide services for students in the learning process, constantly aligning the quality of their education with the needs of the working world in forming professional human resources. In conducting accounts receivable collection to students, besides going through cashier who is in charge of receiving payment from students in counter, the collecting process can be done by class treasurers or financial staff in charge chosen by the Chief Financial Officer. Class treasurers' are in charge of monitoring students' installment from the first installment until the full tuition fees for the current semester.

In addition, because STIAMI's activity is an educational service unit, especially for undergraduate education, and STIAMI has more than a thousand active students, thus resulting in high accounts receivable. Besides that these accounts must be obtained effortlessly and managed properly, the billing process also must be done according to the specified time, so the company would be able to achieve their goals. Therefore, the implementation of internal control shall correspond with the existing and sufficed functions as a means to make the recording, billing, and presentation of the financial statements more efficient. Subsequently, it would be able to suppress the risk of errors, dissipation, and fraud attempts. The lack of internal control audits can heighten the risk of misstatements in financial statements, hence the proper procedures are needed to identify the defiances (Mascha, Lamboy-Ruiz, \& Janvrin, 2018). The proceeding is to group the organization's difficulties in accruals estimation, determining material weaknesses exist, and self-selection bias correction (Doyle, Ge, \& McVay, 2007).

Previous studies have shown that when the internal control of local government organizations is increasingly high, the practice of accounting fraud will be more profound. Conversely, when the internal control system is low, accounting fraud will be elevated. Meanwhile, the interaction between internal control and loyalty does not affect individuals committing accounting fraud in local governments (Tehupuring \& Lingga, 2017). Implementation of the internal control system for cash expenditures at PT. Lestari Berkat Sejahtera in Samarinda was not fully following the elements of a great internal 
control system, as seen from the absence of sudden checks (Surprise Audit) conducted by the owner towards each division, and there was no selection for prospective employees that met the requirements. Nevertheless, the cash expenditures process had function properly, videlicet a distinct separation between functions and responsibilities in the organizational structure for cash expenditures procedure, including cash, finance, cashier, and accounting functions (Firma Yandi, 2014). Overall, KJKS BMT Mandiri Sejahtera Karangcangkring cash receipts had been functioning well, aided by the Administrative, Cashier, Accounting, Billing and Internal Audit functions (Fathoni, 2018).

\section{METHOD}

The approach used in this thesis is descriptive-analytical, scilicet in analyzing and discussing problems, an explanation and description will be described systematically, objectively, and relevantly based on data collected as a basis in shaping judgments. The descriptive-analytical approach was taken to provide an adequate picture of the implementation of internal control and accounts receivable accounting in May 2013-May 2014.

\begin{tabular}{|c|c|c|}
\hline $\begin{array}{l}\text { Internal Control: } \\
\text { Control Environment } \\
\text { Risk Interpretation } \\
\text { Control Activites } \\
\text { Information and } \\
\text { Communication } \\
\text { Supervision and } \\
\text { Monitoring }\end{array}$ & $\begin{array}{l}\text { Account Receivable } \\
\text { Accounting System: } \\
\text { Related } \\
\text { organizations } \\
\text { Authorization System } \\
\text { Recording } \\
\text { Procedures } \\
\text { Documents used }\end{array}$ & $\begin{array}{l}\text { Reability of the } \\
\text { finance report } \\
\text { Compliance } \\
\text { towards provision } \\
\text { and laws applied } \\
\text { Operation } \\
\text { effectiveness and } \\
\text { efficiency }\end{array}$ \\
\hline
\end{tabular}

Diagram 1. Framework

Comparing existing facts with internal control norms is the qualitative approach used in this study. The internal control components are:

1. Control Environment

Division of functions, authorities, and responsibilities towards existing functions in the company, whether or not there is a possibility of double duty or function, and other happenings that may cause internal control deficiencies the company encountered will be addressed.

2. Risk Interpretation

This element encloses the risks that the company would encounter if internal control's weaknesses are still obtained and the necessary actions to overcome the risks.

3. Control Activities 
This element will investigate the authorization procedure in the implementation of the account receivable accounting system which includes authorization, responsibilities and authorization, segregation of duties, documentation, reconciliation, competent and honest employees, and internal audit inspections.

4. Information and Communication

This element will observe data and additional information contained in the full report with the intent to show that communication exists within the company.

5. Supervision or Monitoring

In this element, there will be a review of whether the executed internal control quality is viable already or any correction is still required.

\section{RESULT AND DISCUSSION}

\section{STIAMI's Internal Control}

\section{Control Environment}

STIAMI management highly values integrity and competence. In the company, between one division and the other is affiliated as one entity. Every employee is required to be competence. Recruiting qualified prospective employees is the first milestone in creating competency. The contract system set by the company for new employees is one of the management's attempts to encourage in creating a great human resource to enhance the company's performance. The company has an SOP (Standard Operating Procedure) that must be carried out by every individuals. The SOPs for each division are different because of the various job descriptions of each division. Routine meetings occur at least twice a month, while the leadership meetings occur at least once every month and or on certain important moments. Division meetings are held separately between each division. For instance, for the marketing division, the meeting is chaired by the deputy chairperson III, who also coordinated with the head of the marketing division to give directions about market conditions and strategies to the marketing staff.

Division meeting is a meeting headed by each deputy chairperson and must be attended by each individual. On that occasion, heads of division provide information about their respective division's achievement so their division's performance will be known. Furthermore, every individual has the right to give responses, suggestions or input for improvement, while each deputy chairperson has to coordinate and provide guidance for the heads of division, subdivision, and staff to enhance their performance. For example, there 
are plenty of students in debt, then it is specifically deputy chairperson II's job to instruct the billing process to be further improved.

Structurally, the internal supervisory unit (ISU) is under the auspices of the head of STIAMI. The operational audit went well, and audit activities were carried out in all divisions quarterly. This audit aims to assess whether each individual in each section has carried out work procedures under company standards, as well as measuring whether the work procedures can improve internal control. If the standard procedure failed to generate internal control, then the internal auditor would render recommendations to STIAMI's chairperson to advance internal control to accomplish the company's goals and the objectives of the internal control system as a whole.

\section{a. Risk Interpretation}

Every organization or company is bound to face some risks both from internal and external that can hinder them from achieving their objectives at some point. These risks are associated with establishing goals to be accomplished by the organization, scilicet operations efficiency and effectiveness, reliability of financial statements and compliance. Therefore, each organization or company is obligated to interpret the risks they may face appropriately. STIAMI had interpreted the risks of misstatement possibilities, which arose from internal and external events such as:

1) Placement of new employees in receivables receipts and billings.

2) Changes in the accounts receivable accounting information system.

3) Socialization of the new technology's usage in receivables receipts activity.

4) Changes in accounts receivable accounting utilization principles.

\section{b. Control Activities}

Control activities on accounts receivable at STIAMI can be classified into numerous activities e.g.:

1) New students' admission activities are done by the marketing division, while the head of marketing authorized new students' admissions approval. Moreover, deputy chairperson II and III determined the tuition fees list, student admission requirements, and fees deduction.

2) Responsibility and authorization activities over the transfer of receivables are done by class' personnel and treasurers, like the class cashier and treasurers responsibility in doing receipt transactions, recording receipts as an evidence of receivables deduction, and tuition fees' return, as well as the authority and 
authorization of the head of the financial division and subdivision in leading their subordinates to improve their operating performance to acquire profitability.

3) Segregation of duties by each section or functions associated with receivables such as:

a) The admission section and the recording section for the number of students' recapitulation are separated from each other. Student admissions are arranged by the marketing staff, while the number of students' recapitulation is done by the head of the marketing sub-division, and the head of the marketing division does the authorization.

b) The receptions (cashier and class treasurers) are separated from the recording section (accounting staff). Cashier and class treasures do the payment and account receivable receipts, while the accounting staff does the receivables recording.

c) Accounts receivable collections are different from the recording section (accounting staff). Billing, especially in cooperative classes, is done by each class treasurer while accounts receivable mutation recording is done by the accounting staff. This aims to reduce deviations in the form of errors, fraud, or embezzlement of money or the company's cash.

d) Accounts receivable documentation activities in the shape of:

(1) Cash or bank receipts are printed according to the serial number and maintained based on the print month, year, and number and signed by the head of finance plus stamped with the STIAMI logo.

(2) Students' payment receipts issued by the cashier indicate the reduction of students' accounts receivable who pay in the register and the cashier will file the document according to the month, year, and serial number.

(3) Students' payment receipts issued by the class treasurers will be printed following the serial number, receipt's date and signed by the class treasurers and stamped with the STIAMI logo. The receipts show the reduction in cooperation student's receivables who make payments in the cooperation class. The document will be filed by each class treasurer in the order of month, year and serial number.

(4) Regular student debtors accounts or installments are 
printed according to the major and class year.

(5) Cooperative or non-regular student debtors accounts or installments are printed according to the class and class year.

(6) The class' accounts receivable recap is made by the accounting and accounts receivable section staff which then are reported to the head of finance and archived by the head of finance, accounting staff, and the accounts receivable section itself.

(7) Daily cash statements prepared by the reception cashier from the regular or cooperative or non-regular classes are supporting documents for cash receipts from accounts receivable.

e) Reconciliation and internal audit, reconciliation and internal audit activities related to accounts receivable are:

(1) Accounts receivable section will send a debtor statement to every student periodically to evaluate the accuracy of the accounts receivable recordings made by each class treasurer, especially for cooperative students.

(2) The accounting division has to coordinate bank statements with the accounts receivable collection record. This activity is done by the head of the finance sub-division.

(3) The head of finance sub-division will coordinate the class treasurers' accounts receivable collection recapitulation with the cashier's accounts receivable collection record from the cooperation classes.

(4) Doing cross-check between cash receipts and disbursements (cash opname) from cashier and class treasurers with the existing cash balance record from the cashier and the class treasurers itself. This activity is also done by the head of the finance sub-division daily.

f) Competent employees, employees who perform accounts receivable control in STIAMI are competent, as seen from the management policies, such as:

(1) The selective recruitment of prospective employees procedure is done through selection stages according to their respective fields, in which the applicants have a diploma in accounting economics with a GPA standard of 3,00 the least, and came from an accredited college for cashier staff and class treasurers, and a minimum of bachelor degree and is experienced within the field for the head of finance or accounting sub-division. 
(2) The application of an employment contract system for new employees with three alternative considerations, such as the first alternative is if the employee's performance is above the average, when the contract has expired, they would be appointed as a permanent employee. The second alternative is if the employee's performance is slightly below average, then the contract would be extended until a specified time. The last alternative is if the employee's performance is bad, then their contract would be terminated. The new employee's performance is measured by the division's head every three months through evaluations.

\section{1)Information and communication}

STIAMI's accounts receivable information are from each division who is in charge of the accounts receivable, such as:

a) Information from the marketing division and class treasurers about the prospective and current students' condition. This information is used to determine whether the students have met STIAMI's regulations or not for prospective students, and whether the current students' status as a STIAMI student deserves to be extended or not.

b) Information from marketing about prospective students' current interests. This aims to determine the market share and how much interest do the prospective students have to choose STIAMI as one of the campuses to continue their studies.

c) Data from each class treasurers about the students' payment history, especially for current cooperation students. This intends to anticipate overdue arrears because of students' negligence in paying tuition.

The information then processed and used as a decisionmaking tool by each division's head or deputy chairman which later then is communicated to every individual both formally and informally.

\section{Supervision or Monitoring}

STIAMI's management has ruled definite responsibilities to each individual. The smooth running of accounts receivable is the responsibility of each individual who is in charge of accounts receivable, because between one division and other divisions are related to each other. For instance, the head of finance sub-division is also responsible for students' arrears, either from regular or non- 
regular or cooperation students, so they are also obligated in collecting and to monitor the student's payment. Likewise, the cashier and class treasurers are also obligated in collecting and constantly remind the students to pay their debts actively according to their installment made by the cashier and class treasurers. The appointed class treasurers and cashier are required to work optimally to minimize uncollectible accounts receivable.

Monitoring accounts receivable's steadiness is the head of the finance division's responsibility. Every individual's performance is always monitored based on accounts receivable recapitulation information from treasurers and cashier of the previous period. Hence, from the receivables collection's achievement, there would be an evaluation and the head of finance would follow up to assess each individual's rank. This is related to giving out promotions and rewards or incentives.

\section{Obstacles faced in internal control at STIAMI}

There are a few obstacles found in internal control at STIAMI, a few of them are:

1. Control Function

a. In the accounting and finance division, there was a double-duty found. In the head of accounting and tax position, two officials are supposed to be in this position. But in reality, this position is only occupied by one official, so there was a pile-up of duties, authority, and delegation of responsibilities that may cause the operational implementation, especially in the financial statements presentations, to be hampered and ineffective.

b. The accounting division was indeed done the recording and is separated from the revenue function, however in the implementation, this function sometimes also does the receive accounts receivable payment activity when one of the class treasurers or cashier needs someone to complete the task. Because of that, the accounting division could not do accounts receivable recording and the financial statement would be hampered and did not finish on time.

c. There is a pile-up of duties in the revenue function, especially the cashier. The cashier is only supposed to serve cash receipts and disbursements services, making daily cash recaps and making deposits to the bank. Yet, they had to do recording plans and the realization of regular student payments activity too, when the activity should have been done by the class treasurers who are in charge and responsible for regular students' payment history and students loans recording. 
Analysis of the Accounts Receivable Internal Control System at STIAMI Institute Andrayanti

2. Information System used

Despite of the implementation of computer-based accounts receivable accounting system at STIAMI, there were a few weakness found which had become obstacles in the implementation of internal control, such as:

a. Cooperation class' accounts receivable system recording was still made manually by inputting accounts receivable realization plans to excel and not programmed in the Finance Information System in STIAMI's financial division. In other words, the program was only automatically recapitulating the addition and reduction of regular classes' accounts receivable. So finding out non-regular or cooperation classes' receivable balance is not as easy as the regular classes.

b. Academic Information System that is available in the students' course selection sheet is only for students from regular classes. So when non-regular or cooperation students did some changes in the semester course credit, the accounts receivable bill did not change automatically according to the amount of the student's course credit.

c. The weakness of STIAMI's system in receiving accounts receivable payment activities have caused cash or bank receipts having the same numbers but with different students' name, and resulting in one of the student's payment data lost or was replaced automatically.

d. The course selection form for non-regular or cooperation classes was still being noted and printed manually so students can easily change their course credit without any confirmation to the academic division. This may cause a data mismatch between the finance division and the student itself.

e. Non-regular or cooperation classes' student debtors accounts were also made and printed manually, so when students made their payment, the bill would not change automatically according to the nominal the student has paid.

\section{The efforts that have been made to minimalize the obstacles of the internal control system towards accounts receivable accounting system at STIAMI}

The efforts that have been made by STIAMI's management in minimalizing the obstacles are as follow:

1. Control Function

a. There was a selection for competent employees, especially in tax or accounting division, so they can be recommended as the head of the accounting or tax sub-division. With this position 
and human resources addition separation, hopefully, the workload, authorities, and responsibilities will run effectively.

b. When the class treasurers or cashier could not come, then the delegation of receivables, especially the cooperation class receivables, authority is carried out by the head of finance subdivision, so that the accounting department can continue to carry out its activities as usual.

c. To reduce the cashier's burdening tasks of recording the realization plan for the regular students' accounts receivable receipts, the management held a selection for prospective employees or adding competent human resources, especially in the financial section who would later be assigned as a regular class treasurers' who is going to record the realization of regular students' payment plans and recapitulate regular class receivables.

2. Information System

Due to the differences in using the Financial Information Systems and Academic Information Systems between the regular and nonregular or cooperation classes, the management has made an effort to centralize the existing system and apply it to all classes: regular and non-regular or cooperation classes.

\section{CONCLUSION}

1. The internal control applied in STIAMI. Overall, the internal control procedures towards the accounts receivable accounting system at STIAMI is quite effective, where the company's management has applied the basic concepts and principles of internal control. In addition, the control environment has also run well, indicated by the independence of the audit committee or the internal supervisory unit (ISU) in which are right under the head of STIAMI auspices, as well as the implemented control concept applied by the deputy chairman line and the head of division are going well too. However, there are some procedures that do not reflect the internal control concept yet, such as the ineffective duties segregation, in which the function that collects receivables is the same as the revenue function. According to the control concept, the accounts receivable collector should not occupy the revenue section as well.

2. There are a few obstacles found in the implementation of internal control at STIAMI, scilicet in the control function, there were doubleduty found, namely in the head of accounting and tax position, so there was a pile-up of duties, authority, and delegation of responsibilities that may cause the operational implementation, 
especially in the financial statements presentations, to be hampered and ineffective. Besides, in the Information System used, the accounts receivable recording system for cooperation classes was made manually and not programmed in the Finance Information System in STIAMI's finance division, resulting in data mismatch between the student in non-regular classes with the existing accounts receivable data in the finance division sometimes. Moreover, the time needed to find out the non-regular or cooperation classes' accounts receivable balance was not as easy and fast as the regular classes.

3. The efforts that STIAMI has made in minimalizing the obstacles in the implementation of internal control are as follow: in the control function, there was a selection for competent employees, especially in tax or accounting division, so they can be recommended as the head of the accounting or tax sub-division. With this position and human resources addition separation, hopefully, the workload, authorities, and responsibilities will run effectively. Meanwhile in the Information System, due to the differences in using the Financial Information Systems and Academic Information Systems between the regular and non-regular or cooperation classes, the management has made an effort to centralize the existing system and apply it to all classes: regular and non-regular or cooperation classes.

Based on the conclusion above, then the suggestions the writer can offer are:

1. Internal Control System at STIAMI. In addition to being carried out by the Internal Supervisory Unit owned by STIAMI management, the monitoring and supervision should be carried out by the External Audit as well, in order to achieve the company's internal control objectives, scilicet the reliability of financial statements, compliance towards the laws and regulations applied, and operation's effectiveness and efficiency.

2. The management should have enforced the functions so that the organization can carry out its activities according to their respective functions in order the operations run effectively.

3. The management should centralize the system online, so the access to get information, either finance, academics, study programs or other information are easily obtained.

\section{REFERENCE}

Beasley, M. S., Carcello, J. V., Hermanson, D. R., \& Lapides, P. D. (2000). Fraudulent Financial Reporting: Consideration of Industry Traits and Corporate Governance Mechanisms. Accounting Horizons, 14(4), 
Analysis of the Accounts Receivable Internal Control System at STIAMI Institute Andrayanti

441-454. https://doi.org/10.2308/acch.2000.14.4.441

Bentley-Goode, K. A., Newton, N. J., \& Thompson, A. M. (2017). Business Strategy, Internal Control over Financial Reporting, and Audit Reporting Quality. AUDITING: A Journal of Practice \& Theory, 36(4), 49-69. https://doi.org/10.2308/ajpt-51693

Doyle, J. T., Ge, W., \& McVay, S. (2007). Accruals Quality and Internal Control over Financial Reporting. The Accounting Review, 82(5), 1141-1170. https://doi.org/10.2308/accr.2007.82.5.1141

Fathoni, A. (2018). Sistem Akuntansi Penerimaan Kas Pada Kjks Bmt Mandiri Sejahtera Karangcangkring Gresik Jawa Timur. Al-Idarah: Jurnal Manajemen Dan Administrasi Islam, 2(1), 137. https://doi.org/10.22373/al-idarah.v2i1.3154

Firma Yandi, S. (2014). Analisis Penerapan Sistem Pengendalian Intern Terhadap Pengeluaran Kas Pada Pt. Lestari Berkat Sejahtera Di Samarinda. EJournal Ilmu Administrasi Bisnis, 2(3). Retrieved from https://ejournal.adbisnis.fisip-unmul.ac.id/site/?p=776

Ge, W., \& McVay, S. (2005). The Disclosure of Material Weaknesses in Internal Control after the Sarbanes $\square$ Oxley Act. Accounting Horizons, 19(3), 137-158. https://doi.org/10.2308/acch.2005.19.3.137

Hoitash, U., Hoitash, R., \& Bedard, J. C. (2009). Corporate Governance and Internal Control over Financial Reporting: A Comparison of Regulatory Regimes. The Accounting Review, 84(3), 839-867. https:// doi.org/10.2308/accr.2009.84.3.839

Mascha, M. F., Lamboy-Ruiz, M. A., \& Janvrin, D. J. (2018). PCAOB inspections: An analysis of entity-level and application-level control audit deficiencies. International Journal of Accounting Information Systems, 30, 19-39. https://doi.org/10.1016/j.accinf.2018.06.002

Sofyan, M. (2016). Sistem Pengendalian Intern Pengelolaan Pajak Restoran Dalam Meningkatkan Pendapatan Asli Daerah (PAD) Kota Bogor. Jurnal Eksekutif, 13(1), 59-77. Retrieved from http://jurnal.ibmt.ac.id/index.php/jeksekutif/article/view/107

Tehupuring, R., \& Lingga, R. A. (2017). Sistem Pengendalian Intern Sebagai Prediktor Kecurangan Akuntansi Pada Pemerintah Daerah. Dapatkah Loyalitas Individu Memitigasinya? Jurnal Tata Kelola \& Akuntabilitas Keuangan Negara, 3(2), 113. https://doi.org/10.28986/jtaken.v3i2.111 